\title{
DZIEJE KULTU ŚWIĘTEGO ANTONIEGO Z PADWY W KOŚCIELE OO. BERNARDYNÓW W PRZEWORSKU
}

\begin{abstract}
„,..zaznaczyć się godzi wielką ufność ludzi pokładaną w św. Antonim, którego przyczyny wzywają za pomocą znanego responsorium «Si quaeris»"
\end{abstract}

Jednym z najstarszych klasztorów bernardyńskich w Polsce jest konwent pw. św. Barbary w Przeworsku, funkcjonujący nieprzerwanie od 1465 r. Fundatorem zespołu klasztornego był Rafał Jakub TarnowskiJarosławski (1440-1492), ówczesny właściciel miasta, późniejszy starosta lwowski i marszałek wielki koronny. Decyzja o fundacji spowodowana była nie tylko pobudkami religijnymi możnowładcy, lecz także chęcią zamanifestowania znaczenia rodu i dążeniem do podniesienia prestiżu rozwijającego się miasta. Przybyłym prawdopodobnie z Tarnowa bernardynom przekazał nieukończony kościół, który otrzymał później wezwanie św. Barbary z Nikomedii, oraz część zabudowań klasztornych. Obiekty zlokalizowane były na wzniesieniu, we wschodniej części Przeworska, przy trakcie lwowskim² ${ }^{2}$

Dzięki wsparciu licznych dobrodziejów i korzystnemu położeniu konwent szybko zyskał istotne znaczenie w zakonnej prowincji. W XV-XVI w. wspólnota klasztorna liczyła ponad dwudziestu ojców i braci, dwóch z nich - Grzegorz z Nowego Sącza (†1490) i Piotr Kandyd

\footnotetext{
${ }^{1}$ Archiwum Prowincji Bernardynów w Krakowie [dalej: ABK], sygn. IX-57, Chronica Conventus Przevorscensis Ord. Fr. Minorum vulgo Bernardinorum incip. anno 1884, s. 67.

2 A. Ch a d a m OFM, Przeworsk, [w:] Klasztory bernardyńskie w Polsce w jej granicach historycznych, red. H. E. W y c z a w s k i OFM, Kalwaria Zebrzydowska 1985, s. 278; P. G ą s i o row s k a, Rafat Jarosławski - fundator klasztoru bernardynów w Przeworsku, [w:] 550 lat obecności oo. Bernardynów w Przeworsku (1465-2015), red. A. K. S i t n i k OFM, M. R. G ę ś 1 a OFM, Kalwaria Zebrzydowska 2015, s. 49-50.
}

„Nasza Przeszłość” t. 132: 2019, s. 219-244. 
$(† 1495)$ zmarło w opinii świętości. Czterokrotnie urządzano w klasztorze przeworskim kapituły prowincjalne (1489, 1539, 1646 i 1690), pierwszej z nich przewodniczył bł. Władysław z Gielniowa. Oblicze klasztoru kształtowali wybitni gwardianie: Hieronim Kakowski, Wincenty Morawski, czy Hadrian Seryewicz Przez pewien czas w klasztorze funkcjonował nowicjat, a w 1664 r. założono tu studium teologii moralnej i języka łacińskiego. W 1608 r. bernardyni przeworscy dali początek wspólnocie klasztoru w Leżajsku. Zakonnicy przeworscy pełnili duszpasterską posługę wobec bernardynek-koletek, które posiadały swój klasztor w mieście. Przy bernardyńskiej świątyni zorganizowano III Zakon Franciszkański, wkrótce powstały także liczne bractwa, zrzeszające szlachtę i mieszczan ${ }^{3}$.

Charakterystycznym elementem duszpasterstwa prowadzonego przez przeworskich bernardynów był rozwój kultu cudownych obrazów. Szczególną czcią otaczano od 1613 r. wizerunek Matki Bożej Pocieszenia, umieszczony w świątyni przez klasztornego kaznodzieję o. Marka. Tradycja cudowności obrazu przeworskiej Madonny sięga 1647 r. Ołtarz z wizerunkiem stał się ulubionym miejscem modlitwy mieszczan przeworskich i okolicznej szlachty, czego świadectwo stanowiły ofiarowane korony (1623), liczne wota (lata 40. XVII w.), ozdoby ołtarzowe i sukienki (1750) ${ }^{4}$.

Kultowi przeworskiej Madonny dorównywała cześć oddawana św. Antoniemu z Padwy. Pierwsze udokumentowane ślady jego kultu pochodzą dopiero z lat 40. XVII w. Wówczas to dwóch zakonników: o. Franciszek z Przeworska, prowincjał bernardyński w latach 1643-1647,

\footnotetext{
${ }^{3}$ A. Ch a d a m OFM, op.cit., s. 278-281; A. B r uździń s k i, Bernardyni w Przeworsku w okresie staropolskim, [w:] 550 lat obecności..., s. 63-86; A. K. S i t n i k OFM, Bractwa przy bernardyńskim kościele św. Barbary w Przeworsku w okresie staropolskim, „Przeworskie Studia Regionalne” [dalej: PSR], t. 2, 2015, s. 144-145. H. E. W y c z a w s k i OFM, Przeworsk (konwent bernardynek), [w:] idem, Klasztory bernardyńskie w Polsce..., s. 538.

${ }^{4}$ ABK, sygn. RGP-b-2, Laconicum novellae provinciae Russiae titulo Immaculatae Conceptionis Beatissimae Virginis Mariae insignitae aliquotque eiusdem locorum et conventum myrrotheicum, seraphico fratrum minorum regularis observantiae ordini mellifcans collectore fratre Bernardino Kaliski, 1647, s. 68; Sz. W i 1 k, Kulty wotywne w kościele oo. Bernardynów w Przeworsku w XVII-XVIII w. Zarys problematyki, PSR, t. 2, 2015, s. 165-166; idem, Kult obrazu Matki Bożej Pocieszenia w kościele OO. Bernardynów w Przeworsku, [w:] Matka Boska Podkarpacka. Mniej znane wizerunki, red. W. S i w a k, Przemyśl 2018, s. 215-222.
} 
który wiele troski poświęcał swemu macierzystemu klasztorowi oraz o. Ludwik Brzezina, ówczesny gwardian, podjęli się dzieła odnowy wnętrza przeworskiego kościoła w duchu baroku. Wykonany został nowy ołtarz główny św. Barbary z okazałym tabernakulum, położono marmurową posadzkę, na placu przed świątynią wzniesiono krużganki procesyjne ${ }^{5}$.

Pojawiły się też nowe ołtarze boczne, a w jednym z nich umieszczono wizerunek św. Antoniego z Padwy - ,ad finem anni huius [1649] przed samą kapitułą erectus est altare ad honorem sancti Antonii Paduani novum przeciwko kazalnicy, na który ołtarz dał JegoM Pan Tomisławski, dobrodziey nasz f500, dał potym znowu f50 do tego ołtarza" ". Choć wpis nie zawiera imienia fundatora, wydaje się, iż można go utożsamiać ze Stanisławem Tomisławskim h. Prawdzic (†1679), którego sumptem wzniesiono osiem lat później ołtarz ku czci św. Franciszka z Asyżu? ${ }^{7}$.

Zaakcentowane w tej krótkiej zapisce słowo „novum” sugeruje, iż wzniesiony wówczas ołtarz zastąpił starszy o tym samym wezwaniu. Niewykluczone jest bowiem, że w skład pierwotnego wyposażenia klasztornej świątyni wchodził ołtarz poświęcony Padewczykowi, wszak jego kult był powszechny w kościołach bernardyńskich ${ }^{8}$. Nie wiadomo, gdzie dokładnie znajdował się omawiany obiekt. Jeżeli jednak przyjmiemy, że wspomniana „kazalnica” umieszczona była wówczas w miejscu obecnej (pochodzącej z XVIII w.), to przypuszczalnie należałoby antoniański ołtarz lokalizować w zakończeniu nawy północnej, gdzie współcześnie znajduje się ołtarz Świętego Krzyża.

Kronika informuje następnie o umieszczonym w ołtarzu wizerunku: „Zmalował obraz sam świętego Antoniego Xiądz Franciszek, malarz, brat nasz zakonny i spowiednik, tenże to który zmalował także miejscu temu obraz świętej Barbary in magno altari (...), a obadwa te obrazy wystawił robotą śliczną i przednią, ex gratia sibi ab Altissimo data, której posteritas mirabitur, ołtarz zaś złocił albo raczej samą tylko rzezaną robotę Jan, malarz w Jarosławiu, mieszczanin

\footnotetext{
${ }^{5}$ A. B r uźd ziń s k i, op. cit., s. 72-73.

${ }^{6}$ Biblioteka Jagiellońska [dalej: BJ], rkps 98/52, Cathalogus praecipuorum benefactorum loci Przeorscensis ad s. Barbaram V. et M., k. $13 \mathrm{v}$.

${ }^{7}$ Ibidem, k. 16v; A. B r u ź d z iń s k i, op. cit., s. 73.

${ }^{8}$ K. Gru dzi ń s k i OFM, Bernardyni w latach 1772-1970, [w:] Zakony św. Franciszka w Polsce w latach 1772-1970, cz. 3, red. J. B a r OFM, Warszawa 1978, s. 49.
} 
jarosławski"9. Wspomnianym jedynie z imienia zakonnym kapłanem, spod którego pędzla wyszedł przeworski wizerunek św. Antoniego, jest o. Franciszek Lekszycki (1600-1668), bernardyn ${ }^{10}$. Poza źródłową zapiską, za autorstwem przemawia widniejąca w prawym dolnym rogu płótna misa z kropielnicą, stanowiąca swoistą sygnaturę tegoż artysty.

Dyskusyjny pozostaje jednak czas powstania obrazu. Janina Dzik opowiedziała się za rokiem 1649, utożsamiając rok wykonania ołtarza z datą powstania wizerunku. O. Efrem Obruśnik OFM, który przeprowadził głęboką analizę treści ideowych, ikonografii oraz inspiracji formalnych i ikonograficznych związanych z obrazem ${ }^{11}$, wskazał jednak, że dzieło musiało powstać w czasie jedynego udokumentowanego pobytu Lekszyckiego w Przeworsku, czyli w 1645 r. Zakonny malarz opuścił wówczas na pewien czas Dubno, gdzie pracował u księcia Dominika Zasławskiego, aby dla konwentu przeworskiego przygotować obraz przedstawiający apoteozę św. Barbary. W tym samym czasie powstał wizerunek Padewczyka. Przeworskie dzieło jest zatem najstarszym spośród czterech antoniańskich obrazów, które wyszły spod pędzla Lekszyckiego (pozostałe znajdują się w Opatowie, Krakowie i Kalwarii Zebrzydowskiej) ${ }^{12}$.

W XVIII w. przeprowadzono kolejną już zmianę wystroju bernardyńskiej świątyni. Kościół otrzymał osiem rokokowych ołtarzy bocznych $\mathrm{z}$ nastawami $\mathrm{w}$ formie iluzjonistycznych fresków, wzorowanymi na retabulach z kościoła św. Anny w Warszawie ${ }^{13}$. Wizerunek Padewczyka

9 BJ, rkps 98/52, Cathalogus praecipuorum benefactorum loci Przeorscensis ad s. Barbaram V. et M., k. 13v.

${ }^{10}$ Franciszek Lekszycki (ok. 1600-1668) - barokowy malarz zakonny, naśladowca P. P. Rubens a i A. V a n D y cka; autor szeregu obrazów, często monumentalnych, o treściach religijnych, znajdujących się przede wszystkim w kościołach bernardyńskich (m.in. Kalwaria Zebrzydowska, Kraków, Leżajsk, Przeworsk). J. D z i k, Franciszek Lekszycki - malarz religijny baroku, Kalwaria Zebrzydowska 1998, s. 18-30; J. S a m e k, Lekszycki Franciszek, „Polski Słownik Biograficzny”, t. 17, 1972, s. 15-16; M. S k r u d li k, Życie i dzieła malarza bernardyńskiego O. Franciszka Lekszyckiego, Sandomierz 1916, s. 3-67.

11 E. A. Obruśn i k OFM, Obraz św. Antoniego Padewskiego w kościele Ojców Bernardynów w Przeworsku, [w:] 550 lat obecności..., s. 315-358.

12 Ibidem, s. 325-328.

13 I. R o l s k a, Malowane ottarze w kościele oo. Bernardynów w Przeworsku, [w:] 550 lat obecności..., s. 287-296. 
przeniesiono do jednego z nich, zlokalizowanego w nawie północnej (obecnie poświęcony jest św. Annie Samotrzeciej). O tym, że wcześniej znajdował się tu obraz św. Antoniego, świadczy umieszczony w wieńczącym retabulum kartuszu napis „Si quaeris miracula” ${ }^{14}$, czyli incipt responsorium ku czci Padewczyka. Wokół tego utworu ${ }^{15}$ koncentrował się zawsze pozaliturgiczny kult św. Antoniego w Przeworsku. Według zakonnej tradycji zwyczaj śpiewania „Si quaeris” w każdy wtorek dotarł do klasztoru przeworskiego z Sambora, gdzie wprowadzony został w II poł. XVII w. ${ }^{16}$ Zachował się kancjonał opracowany do użytku klasztoru przeworskiego na polecenie o. Tacjana Schuldesa, gwardiana, w 1777 r., w którym to śpiewniku znalazło się także responsorium „Si quaeris”, a także msza o św. Antonim (w tonacji F-dur) ${ }^{17}$.

Szczególnie uroczyście obchodzono w Przeworsku święto św. Antoniego (13 czerwca). Odpust $w$ ten dzień gromadził największe rzesze wiernych spośród wszystkich urządzanych w konwencie przeworskim uroczystości $^{18}$. W 1687 r. gwardian o. January Mulecki podejmował w klasztorze króla Jana III Sobieskiego, który „,na swięty Antoni Padewski die 13 Junii był w kosciele naszym y nabożenstwa słuchał"19.

Unikalnym świadectwem kultu jest XVIII-wieczne kazanie o św. Antonim. Wygłoszone zostało podczas jednego z odpustów w Przeworsku przez ks. Józefa Ignacego Kocieńskiego, kanonika przemyskiego, a na-

\footnotetext{
${ }^{14}$ W. K a p u s t a, Sz. W i 1 k, 550 lat Bernardynów w Przeworsku, Przeworsk 2015, s. 68.

$15 \mathrm{Si}$ quaeris miracula - responsorium przypisywane pierwotnie św. Bonawenturze, w rzeczywistości autorstwa niemieckiego franciszkanina o. Juliana ze Spiry. Tekst zawiera dziękczynienie za szereg łask zyskiwanych za wstawiennictwem świętego: wskrzeszanie umarłych, uzdrawianie chorych, uciszanie żywiołów, odnajdywanie zagubionych rzeczy. Z czasem utwór stał się najpopularniejszą modlitwą ku czci padewczyka. Rola i znaczenie responsorium poparte zostało autorytetem Kościoła - 25 stycznia 1866 r. bł. papież Pius IX nadał odpust cząstkowy odmawiającym „Si quaeris”. N. G o 1 i c h o w s k i OFM, Żywot, cuda i nabożeństwo do św. Antoniego Padewskiego, Kraków 1903, s. 75.

${ }^{16}$ Ibidem.

17 Biblioteka Prowincji Bernardynów w Krakowie, sygn. 53/RL, Cantionale Missarum ad usum Fratrum Minorum Obs. Conventus Preorscensis solerti cura comparatum per R.P. Tacianum Schuldes, ejusdem conventus quardianum vigilantissimum conscriptum die 23 septemb. 1777 anno, s. 170-171.

18 Sz. W i 1 k, Jak św. Antoni zawędrowat do Przeworska, „Posłaniec św. Antoniego z Padwy" [dalej: PŚSA], 2017, nr 4, s. 39-40.

19 BJ, rkps 98/52, Cathalogus praecipuorum benefactorum loci Przeorscensis ad s. Barbaram V. et M., k. 22v.
} 
stępnie wydane drukiem w 1754 r. we Lwowie pt. „Wielka bez miary chwała Wielkiego Cudotwórcy Świętego Antoniego z Padwy (...) w kazaniu niegdyś mianym w Przeworsku u Wielebnych Ojców Bernardynów ogłoszona". Mirakularna tematyka kazania sugeruje, że w przeworskim ośrodku kultu antoniańskiego miały miejsce cuda, wypraszane za wstawiennictwem Padewczyka. Relację o jednym z nich zanotowano na kartach klasztornej kroniki. 8 marca 1718 r. uzdrowiony został z niejaki Mateusz ze Studziana. Człowiek ów od wielu tygodni cierpiał na chorobę głowy, wrócił do zdrowia po modlitwie przed wizerunkiem św. Antoniego w Przeworsku, co sam oficjalnie potwierdził ${ }^{20}$. Wpis ten jest istotny również $\mathrm{z}$ innego powodu - pojawia się $\mathrm{w}$ nim po raz pierwszy określenie „cudowny obraz”, zastosowane względem przeworskiego wizerunku św. Antoniego. Materialnym świadectwem doznawanych łask były dary wotywne składane przez wiernych, lecz kronika klasztoru przekazuje informacje tylko o jednym takim przypadku: 20 stycznia 1771 r. wotum w kształcie księżyca z promieniami ofiarowała niejaka pani Korycka, administratorowa mirocińska ${ }^{21}$.

Osłabienie kultu św. Antoniego następuje po 1772 r., gdy Przeworsk znalazł się w zaborze austriackim. Józefińskie dekrety przeciwko kultowi cudownych obrazów zostały zrealizowane w klasztorze bernardyńskim w 1786 r., gdy zaborca zarekwirował cenne wota składane przez wiernych $^{22}$. W niepamięć odeszły pełne splendoru antoniańskie odpusty, urządzane w okresie staropolskim. Chociaż sam konwent uniknął kasaty, w części budynków umieszczono Institutum Correctionis Presbyterorum - dom poprawy dla duchowieństwa wszystkich diecezji galicyjskich. Osadzano tu księży oskarżonych zarówno o przewinienia moralne, jak i o charakterze politycznym. Instytucja penitencjarna, która funkcjonowała w latach 1822-1869, zdecydowanie negatywnie wpłynęła na poziom życia zakonnego i prowadzone przez bernardynów duszpasterstwo ${ }^{23}$.

\footnotetext{
${ }^{20}$ Ibidem, k. 49r.

21 Biblioteka Zakładu Narodowego im. Ossolińskich we Wrocławiu, sygn. rkps 384/II, Archivum conventus Prevorscensis ex antiquo transcriptum, cuius originale in bibliotheca asservatur, anno Domini 1767, s. 60.

22 Sz. W i 1 k, Kult obrazu Matki Bożej Pocieszenia w kościele OO. Bernardynów w Przeworsku..., s. 223.

23 A. Ch a d a m OFM, op. cit., s. 282.
} 
Odnowienie kultu św. Antoniego bernardyni przeworscy przypisywali o. Rudolfowi Wadze ${ }^{24}$, który u schyłku XIX w. ,,Wznowił i między ludem rozpowszechnił" zwyczaj śpiewania responsorium „Si quaeris miracula” ku czci Padewczyka. W 1911 r. kronikarz klasztoru odnotował, że ,zaznaczyć się godzi wielką ufność ludzi pokładaną w św. Antonim, którego przyczyny wzywają za pomocą znanego responsorium «Si quaeris»" 25 . Okolicznością, która przyczyniła się do rozpowszechnienia czci świętego z Padwy był jubileusz 700-lecia jego narodzenia obchodzony w latach 1894-1895. Na tę okazję zlecono przeworskiemu snycerzowi, Antoniemu Rarogiewiczowi ${ }^{26}$ wykonanie nowego ołtarza dla wizerunku Padewczyka. Spod jego dłuta wyszła jednoosiowa neorokokowa nastawa, którą usytuowano w nawie bocznej, przy południowej ścianie świątyni. W centralnej części retabulum znalazło się dzieło Lekszyckiego. Flankują je konsole $\mathrm{z}$ figurami świętych franciszkańskich, związanych z nurtem obserwanckim: po lewej stronie św. Jan Kapistran (z chorągwią), po prawej zaś św. Bernardyn ze Sieny (z monogramem IHS). W górnych partiach ołtarza umieszczono wolutowe spływy, na których zasiadają putta. Pomiędzy nimi zlokalizowana jest wieńcząca nastawę okazała gloria, w której wśród trzydziestu promieni znajduje się godło franciszkańskie. Cała kompozycja jest wyraźnie zdominowana przez antoniański obraz,

${ }^{24}$ O. Rudolf Waga (8 VI 1832, Kalwaria Zebrzydowska - 21 I 1911, Przeworsk) bernardyn, do zakonu wstąpił w 1858 r., święcenia kapłańskie przyjął w 1864 r. Pełnił funkcje kustosza prowincji i definitora oraz gwardiana w Rzeszowie, Sokalu i Zbarażu, pracował ponadto w Krystynopolu, Lwowie i Kalwarii Zebrzydowskiej, w latach 1892-1897 i 1900-1911 posługiwał w Przeworsku jako spowiednik i kaznodzieja. Zapamiętany został jako człowiek niezwykle pobożny, pokorny i pogodny. Pochowany został na cmentarzu Starym w Przeworsku. ABK, sygn. 403, B. W i e r c i o c h OFM, Żywoty niektórych bernardynów: O. Rudolf Waga, Leżajsk 1938-1939, s. 67.

25 ABK, sygn. IX-57, Chronica Conventus Przevorscensis Ord. Fr. Minorum vulgo Bernardinorum incip. anno 1884, s. 67.

26 Antoni Rarogiewicz (1858-1925) - przeworski snycerz, wywodzący się z rodziny o tradycjach rzemieślniczych, od 1894 r. wielokrotny radny miasta Przeworska, w latach 1917-1922 prezes, a wcześniej wiceprezes i skarbnik Towarzystwa Mieszczan Chrześcijańskich „Gwiazda” w Przeworsku. Specjalizował się w sztuce sakralnej. Dla przeworskiego kościoła bernardynów oprócz ołtarza św. Antoniego wykonał ołtarze: główny (1898-1900) i Matki Bożej Pocieszenia (1896), a także rekonstruował stalle. Prowadził również prace w bernardyńskich świątyniach w Rzeszowie, Leżajsku, Lwowie oraz w kościele parafialnym pw. Ducha Świętego w Przeworsku. A. D w o r z a k, Przeworski snycerz Antoni Rarogiewicz (1858-1925) - zarys twórczości, Modus. Prace z historii sztuki, t. 17, 2017, s. 40. 
którego powierzchnia zajmuje większą część ołtarza, a samo retabulum pełni funkcję swoistego obramowanie dla tegoż wizerunku ${ }^{27}$.

Bernardyni przeworscy czcili św. Antoniego jako tego: „który W szczególniejszy sposób opiekuje się naszym klasztorem"28. Wspierał on zakonników również w egzystencjalnych problemach. 31 lipca $1896 \mathrm{r}$. miało miejsce włamanie do kościoła bernardyńskiego. Włamywacze sprofanowali Najświętszy Sakrament, rozrzucając trzydzieści komunikantów po podłodze, pozostałe siedemdziesiąt kradnąc wraz z puszką. Ojcowie pośpiesznie odśpiewali responsorium „Si quaeris miracula” i w ciągu kilku godzin policja zdołała ująć sprawców ${ }^{29}$. Inna sytuacja miała miejsce w 1926 r. Pojawiła się wówczas możliwość elektryfikacji klasztornej świątyni, lecz bernardynów nie było stać na taki wydatek. Zwrócono się więc do św. Antoniego, a on „sam wyszukał dobrodzieja", który pokrył koszty instalacji. Dobrodziejem tym okazała się cukrownia przeworska ${ }^{30}$.

Od końca XIX stulecia aktywnie działało przy kościele przeworskich bernardynów Pobożne Stowarzyszenie Świętego Antoniego ${ }^{31}$. Głównym celem organizacji było uwielbianie Boga za osobę Padewczyka, podejmowanie działań prowadzących do nawrócenia pogan, innowierców, heretyków i grzeszników oraz modlitwa w intencji wzrostu duchowego zakonników, aby „nie przestali szukać na wzór św. Antoniego skarbu ducha serafickiego" 32 , ponadto pomoc ubogim i potrzebującym. Członkowie zobowiązani byli do codziennego odmawiana trzech „Chwała Ojcu” oraz responsorium „Si quaeris”, praktykowania jałmużny oraz

${ }^{27}$ Sz. W i 1 k, Święty Antoni Przeworski, módl się za nami, „Niedziela. Edycja Przemyska" [dalej: NEP], nr 26/2016, s. 6-7.

28 ABK, sygn. IX-57, Chronica Conventus Przevorscensis Ord. Fr. Minorum vulgo Bernardinorum incip. anno 1884, s. 115.

${ }^{29}$ ABK, sygn. IX-1, Akta klasztoru Bernardynów w Przeworsku, 1678-1948, s. 21-30.

30 ABK, sygn. IX-57, Chronica Conventus Przevorscensis Ord. Fr. Minorum vulgo Bernardinorum incip. anno 1884, s. 115.

31 Pobożne Stowarzyszenie Świętego Antoniego - międzynarodowa organizacja religijna założona w 1894 r. przy bazylice św. Antoniego w Rzymie, gdzie zlokalizowano jej główną siedzibę. Krajowa siedziba stowarzyszenia dla obszaru Galicji, a po odzyskaniu niepodległości narodowa dla całej Polski mieściła się we Lwowie. Krajowym, a potem narodowym dyrektorem stowarzyszenia był każdorazowy minister prowincji Niepokalanego Poczęcia Najświętszej Maryi Panny Zakonu Braci Mniejszych. N. G o li c h o w s k i OFM, op. cit., s. 193-195.

32 Ibidem, s. 194. 
uczestniczenia w uroczystościach ku czci św. Antoniego. Asystentem przeworskiego oddziału stowarzyszenia był każdorazowy gwardian klasztoru. Biskup przemyski, na którego terenie diecezji znajdował się Przeworsk, zaaprobował Pobożne Stowarzyszenie Świętego Antoniego kurendą z 16 grudnia 1895 r. $^{33}$.

W krótkim czasie organizacja ta stała się niezwykle popularna, zrzeszając setki wiernych. W latach 1917-1938 do stowarzyszenia wstąpiło co najmniej 1404 osoby. Wśród zapisanych dominowały kobiety (66\%). Najwięcej nowych członków pozyskano w latach 1931-1932 w związku z obchodzonym jubileuszem 700-lecia śmierci św. Antoniego. Do stowarzyszenia należeli mieszkańcy 52 miejscowości. Najwięcej członków rekrutowało się z miasta Przeworska (20\%), liczne grupy wiernych pochodziły z Rozborza (125 - 10,96\%), Studziana $(74-6,49 \%)$ i Gniewczyny $(81-7,1 \%)$. Wśród zapisanych do organizacji dominowali mieszkańcy wsi położonych $\mathrm{w}$ promieniu $5 \mathrm{~km}$ od klasztoru $(61,17 \%)$, należących do przeworskiej parafii pw. Ducha Świętego ${ }^{34}$.

Świętego Antoniego z Padwy szczególnym kultem otaczali także bracia i siostry przeworskiej wspólnoty III Zakonu Franciszkańskiego $^{35}$. 13 czerwca był w Przeworsku jednym $\mathrm{z}$ trzech głównych świąt tercjarskich (obok Niepokalanego Poczęcia NMP i św. Franciszka z Asyżu). Z okazji jubileuszu 700-lecia śmierci św. Antoniego bernardyni zorganizowali dla tercjarzy rekolekcje w dniach

\footnotetext{
33 Ibidem, s. 195.

34 ABK, sygn. IX-13, Księga Stowarzyszenia św. Antoniego przy kościele Bernardynów w Przeworsku, 1917-1938, s. 3-40; ABK, sygn. IX-41, Księa bractw przy kościele OO. Bernardynów w Przeworsku: II. Stowarzyszenie św. Antoniego z Padwy, 1915-1925, s. 84-91.

35 III Zakon Świętego Franciszka w Przeworsku został odnowiony 4 października 1882 r. przez o. Maurycego Miętusa, ówczesnego gwardiana. W pierwszym roku istnienia do organizacji zapisało się 71 osób, a w 1912 r. liczba członków wynosiła 594. Tercjarze rekrutowali się przede wszystkim z terenu Przeworska i najbliższych wsi. Dzięki zaangażowaniu przeworskich bernardynów grupy III Zakonu powstały na pocz. XX w. przy kilkunastu okolicznych parafiach. Tercjarze przeworscy prowadzili zróżnicowane życie religijne, fundowali szaty i paramenty liturgiczne, dysponowali własną biblioteką. ABK, sygn. IX-12, Księga Trzeciego Zakonu św. Franciszka przy kościele Bernardynów w Przeworsku, 1882-1897, s. 67; ABK, sygn. IX-57, Chronica Conventus Przevorscensis Ord. Fr. Minorum vulgo Bernardinorum incip. anno 1884; ABK, sygn. RGP-a-22, Zapiski z wizyty kanonicznej rozpoczętej d. 23.4.1912, s. 213; Przeworsk. Sprawozdanie z działalności Kongregacji III. Zakonu, z ubiegłego r. 1931, „Wiadomości Tercjarskie”, 1932, nr 18, s. 193.
} 
16-18 kwietnia 1931 r. Członkowie III Zakonu zajmowali się propagowaniem „Chleba św. Antoniego” (1920). Wstępując do wspólnoty, często przyjmowali podczas obłóczyn imię „Antoni” lub „Antonina” na cześć Padewczyka ${ }^{36}$.

Zachowały się opisy uroczystości odpustowych św. Antoniego z 1919 r. Sam dzień odpustu poprzedzała, tak jak obecnie, dziewięciowtorkowa nowenna zaczynająca się najwcześniej 11 kwietnia, zaś najpóźniej 17 kwietnia. Sprawowano wówczas uroczystą mszę wotywną z kazaniem o godz. 8.00 poprzedzoną śpiewem hymnu do Ducha Świętego. W 1919 r. uzyskano w kurii przemyskiej przywilej na celebrowanie tej liturgii przed wystawionym Najświętszym Sakramentem. Następnie odczytywano prośby, odmawiano trzykrotnie Ojcze nasz..., Zdrowaś Maryjo... i Chwała Ojcu... oraz śpiewano responsorium „Si quaeris”. Autor relacji zauważył, że w nowennie „uczestniczy bardzo wielu pobożnych czcicieli tego Wielkiego Świętego"37. W wigilię uroczystości odprawiano nieszpory, po których odbywała się procesja wewnątrz kościoła. W sam dzień odpustu sprawowano o 9.00 mszę przed ołtarzem świętego, poprzedzoną obrzędem poświęcenia lilii. O 10.30 celebrowana była suma z kazaniem, następnie odbywała się procesja po placu kościelnym. Po południu odprawiano nieszpory. Autor relacji konkludował: ,ponieważ na ten odpust licznie się gromadzą ludzie, przeto większą liczbę komunikantów zawczasu trzeba przygotować do konsekracji" ${ }^{38}$.

Aby ożywić kult św. Antoniego, o. Tadeusz Ukleja, gwardian w latach 1924-1927, sprowadził do klasztoru cząstkę jego relikwii. Certyfikat autentyczności sporządził 7 października 1924 r. biskup Augustyn Zampini, prefekt zakrystii papieskiej. Partykułę umieszczono w eklektycznym relikwiarzu, który podawano do ucałowania wiernym podczas nabożeństw ${ }^{39}$.

W księdze cudów przygotowanej w 1925 r. w związku ze staraniami o koronację obrazu Matki Bożej Pocieszenia w Przeworsku

\footnotetext{
36 ABK, sygn. IX-12, Księga Trzeciego Zakonu św. Franciszka przy kościele Bernardynów w Przeworsku, 1882-1897, s. 67; Przeworsk. Sprawozdanie z działalności Kongregacji III. Zakonu, z ubiegłego r. 1931..., s. 193.

37 ABK, sygn. IX-15, Porządek nabożeństw rocznych przy kościele Bernardynów

w Przeworsku, spisany 1919 r., s. 20.

38 Ibidem, s. 32.

${ }^{39}$ ABK, sygn. IX-1, Akta klasztoru Bernardynów w Przeworsku, 1678-1948, s. 21-30.
} 
notowano również łaski doświadczone za wstawiennictwem św. Antoniego, których zapisywanie kontynuowano również następnych latach. Z okresu 1852-1960 pochodzi szesnaście takich świadectw złożonych przez wdzięcznych czcicieli. Dotyczą one głównie mieszkańców Przeworska, ale także okolicznych miejscowości (Mokrej Strony, Rozborza, Gorliczyny); w jednym przypadku pojawia się mieszkanka Krakowa. Przedmiotem łaski są najczęściej uzdrowienia, ale występuje też podziękowanie za ocalenie podczas I wojny światowej, uratowanie od pożaru, czy odnalezienie ukradzionej własności. Złożeniu świadectwa zawsze towarzyszyło przekazanie wotum - najczęściej były to srebrne lub złote serca, ale ofiarowywano również bransoletki, obrączki ślubne czy świece wotywne. Wzruszającym wyrazem religijności są korale przekazywane przez czcicielki św. Antoniego. Wiele z nich zostało skradzionych podczas I wojny światowej - w 1925 r. przy obrazie znajdowały się tylko 23 wota $^{40}$.

W 1911 r. kierowniczka szkoły żeńskiej w Przeworsku Amelia Wollówna złożyła podziękowanie za uratowanie od pożaru. Kobieta postanowiła jakiś czas wcześniej przekazywać na „chleb Świętego Antoniego" równowartość kwoty pobieranej za ubezpieczenie. Pewnej nocy zapaliły się belki nad mieszkaniem Wollówny i tliły się do rana, kiedy to dostrzeżono powstały pożar. Świadkowie ze zdziwieniem stwierdzili, że mimo znacznego uszkodzenia wiązania dachu sufit nie zawalił się. Dzięki temu ocalona została nie tylko Amelia, ale również pozostali mieszkańcy domu ${ }^{41}$.

Wśród świadectw są także podziękowania za otrzymanie łaski zdrowia. Maria Jędrzejec z podprzeworskiej Maćkówki dziękowała w 1925 r. za uzdrowienie córki. Dwunastoletnia dziewczynka zachorowała na dziwną chorobę - nogi trapiły ogromne bóle, zaś ręce i głowa pokryły się wrzodami. Kobieta obiecała, że jeżeli córka wyzdrowieje, ofiaruje na „chleb Świętego Antoniego” tyle pszenicy, ile dziewczynka zaważy. Gdy córka wróciła do zdrowia, Maria z radością wypełniła swe zobowiązanie ${ }^{42}$.

\footnotetext{
40 Archiwum Klasztoru Bernardynów w Przeworsku [dalej: ABP], b. sygn., [T. U k l e j a OFM], Cuda i łaski doznane za przyczyna Matki Bożej Pocieszenia i Świętego Antoniego Padewskiego, 1852-1960, k. 2r-10r.

${ }^{41}$ Ibidem, k. 4v-5r.

${ }^{42}$ Ibidem, k. 5v.
} 
Łaski uzdrowienia doznał również dziewięcioletni Czesław Sadło. Podczas zabawy uległ on nieszczęśliwemu wypadkowi i uszkodził sobie kręg w szyi. Lekarz stwierdził, że konieczna jest operacja. Chłopiec, bojąc się zabiegu, modlił się gorliwie za wstawiennictwem św. Antoniego, nazajutrz ku zdziwieniu medyków stan jego zdrowia znacznie się poprawił, a w kolejnych dniach Czesław wrócił całkowicie do zdrowia. Uzdrowienia doznał także Jan Kapusta z Bud Przeworskich. W 1926 r. mężczyzna zachorował na zapalenie stawów i nerwów w prawej nodze. Lekarze stwierdzili, że jedynym wyjściem jest amputacja kończyny, nie dawali jednak gwarancji, że Jan przeżyje operację. Mężczyzna nie zgodził się na zabieg, a wraz z żoną Zofią polecił się ufnie orędownictwu św. Antoniego. Okazało się wkrótce, że noga wróciła do pełnej sprawności i operacja nie była potrzebna ${ }^{43}$.

Anonimowa mieszkanka parafii przeworskiej złożyła podziękowanie za uzdrowienie syna, który przez rok cierpiał na ból nogi. Z uwagi na trudną sytuację materialną rodziny, matka przekazała choremu niewielką kwotę pieniędzy, która miała starczyć na jedną wizytę u lekarza, sama zaś przybyła do kościoła przeworskich bernardynów, gdzie przed ołtarzem św. Antoniego błagała o ratunek. Zanoszone modlitwy miały zostać wysłuchane, gdyż syn nie zażył żadnego lekarstwa, a wrócił od medyka, nie odczuwając żadnych dolegliwości. Podobna sytuacja dotyczyła Józefa Wilka, syna Katarzyny i Michała z Rozborza. Zapadł on na zapalenie stawów, a lekarz z Jarosławia, do którego udano się po poradę, orzekł, iż choroba wymaga długotrwałego leczenia. Matka poleciła Józefa wstawiennictwu św. Antoniego, po czym bóle ustąpiły. Za jakiś czas powróciły ponownie, z tym większą jednak ufnością modlono się do Padewczyka, aż w końcu syn wrócił do pełni zdrowia ${ }^{44}$.

Nietypowe wotum złożyła przeworska nauczycielka Maria Sławińska. Wdzięczna Padewczykowi za otrzymane łaski, wskazywała, że „nie zawiodła jej nigdy prośba z ufnością u stóp Jego ołtarza zaniesiona”. Za liczne dobrodziejstwa doznane przez przyczynę św. Antoniego, a wśród nich „uzdrowienie kilkukrotne dzieci z ciężkiej choroby” postanowiła sprawić szafkę na wota składane przez czcicieli świętego z Padwy. Zainicjowała zbiórkę datków na ten cel, sama pierwsza

\footnotetext{
43 Ibidem, k. 6r-7r.

${ }^{44}$ Ibidem, k. 6v-7r.
} 
przekazując pieniężną ofiarę ${ }^{45}$. Ufundowane szafki umieszczono po obu stronach antoniańskiego ołtarza.

Obraz powszechnie określano mianem „cudownego” lub „łaskami słynącego". Czciciele często nazywali wówczas św. Antoniego wielkim cudotwórcą. Taki tytuł znalazł się również na drukowanych reprodukcjach antoniańskiego wizerunku rozprowadzanych przed 1898 r. jako cegiełki na wykonanie nowego ołtarza głównego. W relacjach rocznych na kongresy międzykapitulne w Leżajsku (m.in. 1931, 1932) odnotowano „obraz cudowny św. Antoniego”, wymieniając go nawet przed wizerunkiem Matki Bożej Pocieszenia ${ }^{46}$. Przekonanie o cudowności wizerunku podzielali także zwierzchnicy bernardyńskiej prowincji. We wpisie wizytacyjnym z 16 lipca 1931 r. prowincjał o. Cyprian Jurkiewicz zanotował życzenie pod adresem przeworskich zakonników: ,providentia divi Antonii Patavini miraculosi in ecclesia ista Przeworscensi sit semper vobiscum"47.

Również w czasie II wojny światowej kult św. Antoniego, choć ograniczony, nie zanikł. W lipcu 1941 r. udało się nawet bernardynom przeprowadzić doraźną renowację ołtarza antoniańskiego, a ofiarę na ten cel złożyła Teresa Pruchnicka z Rozborza ${ }^{48}$. Z okresu okupacyjnego pochodzi także interesujące świadectwo o doznanej łasce. Hitlerowcy złapali w Przeworsku młodego chłopaka z bronią w ręku, zapewne uczestnika antyniemieckiej konspiracji. Jego matka przybiegła do klasztoru i zwróciła się do ówczesnego gwardiana, o. Rufina Janusza z prośbą o odśpiewanie „Si quaeris” w intencji syna. Gwardian wspominał: „Odśpiewałem, ale nie wierzyłem, żeby chłopak został uwolniony". Po kilku dniach matka znów przyszła do klasztoru, prosząc o odśpiewanie „Si quaeris”, tym razem dziękczynnego ${ }^{49}$.

W 1962 r. ołtarz św. Antoniego przeniesiono do kaplicy bocznej przylegającej do nawy północnej. Obiekt ten wzniesiony został w 1757 r. na miejscu starszej kaplicy grobowej Jana Szomowskiego. Inicjatorem jej powstania był o. Eleuteriusz Kromczyński, a budowano ją dla otoczo-

\footnotetext{
45 Ibidem, k. 7r.

46 ABK, sygn. IX-112, Akta klasztoru Bernardynów w Przeworsku, 1848-1974, s. $313,317$.

${ }^{47}$ ABP, b. sygn., Liber visitationis (ab an. 1910), k. 6v.

48 ABK, sygn. IX-1, Akta klasztoru Bernardynów w Przeworsku, 1678-1948, s. 207.

49 A. K. S i t n i k OFM, Działalność bernardynów przeworskich po II wojnie światowej (1944-2014), [w:] 550 lat obecności..., s. 194.
} 
nego wówczas kultem obrazu Pana Jezusa Biczowanego. W latach 1896-1962 znajdował się tu cudowny wizerunek Matki Bożej Pocieszenia $^{50}$. Ponieważ dokonano jego uroczystej intronizacji do głównego ołtarza (25 sierpnia 1962 r.), kaplica zwolniła się ${ }^{51}$. Postanowiono zatem umieścić w niej wspomniany już pochodzący z końca XIX w. ołtarz wraz z obrazem św. Antoniego. Następnie podjęto restaurację wnętrza (20 września 1968 - 6 lipca 1969), którą przeprowadził Józef Steciński, nauczyciel z liceum plastycznego w Jarosławiu. Polichromię obmyto wodą amoniakalną, uzupełniono tynki i ornamenty złocenia, wreszcie odmalowano płaszczyzny gładkie ścian. Konserwacji poddano także sam obraz św. Antoniego. 6 lipca 1969 r. odbyło się uroczyste poświęcenie kaplicy ${ }^{52}$.

Kiedy w 1966 r. pokryto ściany kościoła polichromią autorstwa Józefa Dutkiewicza, jedno z malowideł zlokalizowane nad wejściem do bocznej kaplicy przedstawiało pokłon składany św. Antoniemu przez króla Jana III Sobieskiego. Z uwagi na nowoczesność formy wspomniany wystrój świątyni był powszechnie krytykowany przez zakonników i wiernych, choć antoniańskie przedstawienie wydawało się najbardziej interesującym. W 1978 r. zamalowano wszystkie freski, a wśród nich również ten przedstawiający polskiego króla u stóp przeworskiego obrazu Padewczyka ${ }^{53}$. Do rozwoju kultu św. Antoniego z Padwy przyczynił się wzrost znaczenia przeworskiego klasztoru bernardynów w związku z utworzeniem przy klasztornej świątyni ośrodka duszpasterskiego. Najpierw, 1 lutego 1971 r. bp Ignacy Tokarczuk erygował wikariat samodzielny, a dziesięć lat później nadał mu status parafii $^{54}$. Odpust antoniański stał się jednym z najistotniejszych dni w kalendarzu liturgicznym nowej jednostki, ciesząc się większą popularnością

${ }^{50}$ D. B i e d r oń s k a - K ró w k a, R. K a l i n o w s k i, Historia kaplicy zwanej dziś kaplica św. Antoniego $w$ bernardyńskim kościele pod wezwaniem św. Barbary w Przeworsku, w świetle prac konserwatorskich oraz wedtug źródet, [w:] 550 lat obecności..., s. 360-372.

51 A. K. S i t n i k OFM, Działalność bernardynów przeworskich...., s. 197-198.

${ }^{52}$ D. B i e d rón s k a - K ró w k a, R. K a l i n ow s k i, op. cit., s. 372.

53 A. Ch a d a m, op. cit., s. 283; B. M i g d ał OFM, Z Przeworska: Kościót w nowej szacie, „Vita Provinciae" [dalej: VP], R. 16, 1979, z. 1, s. 37; W. K a p u s ta, Sz. W i 1 k, op. cit., s. 36.

${ }^{54}$ A. K. S i t n i k OFM, Działalność bernardynów przeworskich..., s. 178. 
niż uroczystość św. Barbary z Nikomedii, patronki parafii, czy obchód ku czci Matki Bożej Pocieszenia $z$ łaskami słynącego wizerunku ${ }^{55}$.

Jeszcze przed utworzeniem wikariatu czerwcowy odpust był przenoszony na najbliższą niedzielę, ,ze względu na ludzi zatrudnionych w zakładach pracy i na roli" ${ }^{\prime 6}$. Wierni nie zawodzili pod względem frekwencji - w 1971 r. kronikarz odnotował, że uroczystość zgromadziła około ośmiu tysięcy osób ${ }^{57}$. W kolejnych latach zdecydowano się antoniańskie święto organizować ipsa die. W następującą niedzielę urządzano zaś Dzień Chorych połączony z pielgrzymką wiernych z dekanatów przeworskiego i kańczuckiego. Koordynatorem przedsięwzięcia był ks. Józef Burda, diecezjalny duszpasterz chorych. Inicjatywa cieszyła się popularnością, a chorzy „byli bardzo zadowoleni i wdzięczni, że ktoś o nich pamiętał" 58 . Po 1991 r. zaprzestano jednak tej praktyki. W następnych latach chorych zapraszano na jedną z mszy w dniu 13 czerwca, podczas której udzielano sakramentu namaszczenia chorych i indywidualnego błogosławieństwa Najświętszym Sakramentem ${ }^{59}$.

Obrzędem towarzyszącym odpustowi św. Antoniego z Padwy było i jest błogosławieństwo udzielane małym dzieciom. Na kartach kroniki niejednokrotnie notowano, że z całej okolicy przybywają matki, przyprowadzając swe potomstwo, aby kapłan udzielił im indywidualnego błogosławieństwa. W odpuście biorą także udział uczniowie działającej na terenie parafii Szkoły Podstawowej nr 2 im. Hugona Kołłątaja wraz z wychowawcami, niekiedy pielgrzymowały tu także dzieci ze Szkoły Podstawowej im. św. Antoniego z Padwy w Urzejowicach.

W 1973 r. o. Alfons Śmigiel (1914-1993) zapisał na kartach parafialnej kroniki, że św. Antoni: „W Przeworsku cieszy się największą czcią i kultem z wszystkich klasztorów naszej Prowincji i śmiało można powiedzieć, że w całej Polsce nie ma takiego miejsca, gdzie by wypraszał tyle łask". Bernardyni mieli zatem świadomość jak ogromny jest potencjał związany z przeworskim ośrodkiem kultu Padewczyka. Nie podjęto jednakże żadnych działań zmierzających do uzyskania statusu sanktuarium.

\footnotetext{
55 Archiwum Parafii pw. Świętej Barbary w Przeworsku [dalej: AŚBP], b. sygn., Kronika parafii św. Barbary w Przeworsku, t. I, 1971-1981, s. 12.

56 Ibidem, s. 38.

57 Ibidem, s. 12.

58 Ibidem, s. 64, 94-95.

${ }^{59}$ AŚBP, b. sygn., Kronika parafii św. Barbary w Przeworsku, t. II, 1981-2008, s. 148.
} 
Notowano, jednakże łaski doznane za wstawiennictwem św. Antoniego. W 1980 r. wdzięczni dziadkowie Leon i Sabina Trybalscy z Przeworska składali podziękowanie za uzdrowienie kilkuletniego wnuczka Jacka, mieszkającego w Warszawie. Chłopiec trafił do szpitala $\mathrm{z}$ obustronnym zapaleniem płuc, a stan jego zdrowia $\mathrm{z}$ godziny na godzinę się pogarszał. Dano znać do klasztoru przeworskiego, prosząc ojców o odśpiewanie „Si quaeris”, co bernardyni natychmiast uczynili. W tym samym dniu ponownie dokonano prześwietlenia rentgenowskiego, które nie wykazało żadnej choroby. Znający wcześniejszą diagnozę ordynator oddziału dokładnie przebadał chłopca i nie stwierdził żadnych zmian w organizmie. Wszystko to rozegrało się w ciągu 24 godzin. Świadectwo kończy się stwierdzeniem: „Wielce uradowani wprost cudownym odzyskaniem zdrowia naszego wnuczka, wyrażamy hołd i bezgraniczną ufność w cudowną moc sługi Bożego Świętego Antoniego" ${ }^{\circ 0}$. Tekst podziękowania przedrukowano następnie w bernardyńskim czasopiśmie „Vita Provinciae" ${ }^{\text {61 }}$.

W następnych latach na różne sposoby oddawano cześć św. Antoniemu. Przykładowo, w 1974 r. przy okazji wykonywania nowych dzwonów dla klasztoru przeworskiego, jeden z nich o masie $825 \mathrm{~kg}$, nastrojony w tonacji „Fis” poświęcono świętemu z Padwy. Na płaszczu dzwonu umieszczony został napis: „Imię moje Antoni - O Święty Antoni, niech nas przed Bogiem twoja prośba broni" "62.

Współcześnie kult św. Antoniego z Padwy jest nadal niezwykle żywy, o czym świadczy liczny udział wiernych w czerwcowym odpuście, poprzedzającej go nowennie oraz nabożeństwach w każdy wtorek. Rokrocznie składanych jest niemal 10 tysięcy próśb i podziękowań zanoszonych do Boga przez przyczynę Padewczyka. Ponadto bernardyni odśpiewują responsorium „Si quaeris” w każdy dzień tygodnia, na prośbę wiernych, którzy w nagłych sytuacjach, proszą o to swoich duszpaste$\mathrm{rzy}^{63}$. Pod patronatem Padewczyka działa w parafii grupa charytatywna oraz jedna $\mathrm{z}$ róż różańcowych ${ }^{64}$. Wierni pielgrzymują także do sanktua-

\footnotetext{
${ }^{60}$ A. K. S i t n i k OFM, Działalność bernardynów przeworskich..., s. 194-195.

61; B. M i g d ał OFM, Z Przeworska: Uzupetnienia z 1980. Święty Antoni działa, VP, R. 18, 1981, z. 2-3, s. 59-62.

62 Idem, Z Przeworska: Dzwony, VP, R. 11, 1974, z. 2, s. 21-22.

63 B. Ch m u r a, Święty Antoni będzie się opiekowat mieszkańcami, „Życie Podkarpackie" [dalej: ŻP], 2017, nr 23 (2560), s. 16.

${ }^{64}$ W. K a p u s t a, Sz. W i 1 k, op. cit., s. 205.
} 
riów i innych ośrodków kultu św. Antoniego z Padwy (Łódź-Łagiewniki - VII 2016; Radecznica - IX 2016; Dąbrowa Górnicza-Gołonóg - VII 2017; Józefów nad Wisłą - VIII 2017; Chełm - VII 2018) ${ }^{65}$. Z inicjatywy o. Marcelego Gęśli, gwardiana w latach 2011-2016, przeprowadzono gruntowną renowację kaplicy św. Antoniego. Odkryte zostały freski ornamentalne z XVIII w., poza tym restauracji poddano XIX-wieczne freski maryjno-franciszkańskie, witraże, ołtarz i cudowny obraz. Poświęcenia odnowionej kaplicy dokonał 13 czerwca 2015 r. abp Herkulan Piotr Maluczuk OFM, ordynariusz kijowsko-żytomierski ${ }^{66}$.

Oprócz czczonego jako cudowny wizerunku autorstwa Lekszyckiego w kościele znajdują się inne przedstawienia świętego. Nad stallami od strony północnej umieszczony jest owalny kartusz przedstawiający Padewczyka datowany na XVIII w. W krużganku wschodnim, obok zakrystii, naprzeciw wejścia na ambonę znajduje się pochodzący z jednego z klasztorów kresowych obraz św. Antoniego, o kształcie sugerującym, że znajdował się niegdyś w nastawie ołtarzowej. W 1939 r. III Zakon ufundował feretron świętego, noszony również obecnie podczas procesji. Na zewnątrz, od strony wschodniej kościoła umieszczono w latach 70. XX w. figurę świętego na kolumnie. Również za furtą klasztorną znajdują się wizerunki św. Antoniego - w refektarzu fresk w kształcie plafonu, a w korytarzu klasztornym na piętrze olejny obraz przedstawiający świętego malowany przez bliżej nieznaną M. Podlarską, oba z pocz. XX w. ${ }^{67}$.

Kult św. Antoniego oddziałuje również na sąsiednie parafie. W bazylice mniejszej pw. Ducha Świętego (dawny kościół bożogrobców) umieszczono na pocz. XX w. neobarokowy ołtarz św. Antoniego, a w przeworskich kościołach: Matki Bożej Śnieżnej i Chrystusa Króla znajdują się figury świętego. Przejawem ludowej pobożności z terenu miasta i okolicznych wsi są liczne kapliczki poświęcone św. Antoniemu. Szczególnie interesująca historia wiąże się z powstaniem zlokalizowanej przy ul. Węgierskiej w Przeworsku. W 1747 r. z kancelarii Antoniego Lubomirskiego (1718-1782), ówczesnego właściciela miasta wyszedł

${ }^{65}$ AŚBP, b. sygn., Kronika parafii św. Barbary w Przeworsku, t. III, od 2008, s. 126, $129,142$.

${ }^{66}$ W. K a p u s t a, Sz. W i 1 k, op. cit., s. 99.

${ }^{67}$ Ibidem, s. 130, 152, 159. 
uniwersał, zobowiązujący mieszczan do uzyskania nadzwyczajnego zezwolenia na oddawanie synów do stanu kapłańskiego lub zakonnego. Syn rzeźnika przeworskiego, Franciszka Pięciakowskiego, rozpoczął nowicjat u dominikanów, nie uzyskawszy zgody księcia. W efekcie jego rodzice zostali postawieni przed sądem zamkowym i na mocy wyroku z 24 września 1758 r. skazano ich na konfiskatę domostwa oraz dwutygodniowe więzienie. Dopiero po odwołaniu się do samego Lubomirskiego uzyskali zmniejszenie wyroku i zastąpienie przepadku mienia karą grzywny. Z wdzięczności za łaskę udzieloną przez księcia wznieśli kapliczkę ku czci patrona właściciela Przeworska z późnobarokową figurą Padewczyka ${ }^{68}$. Oryginalna rzeźba została z czasem przeniesiona do Muzeum w Przeworsku Zespołu Pałacowo-Parkowego, w 2015 r. poddano ją gruntownej renowacji ${ }^{69}$.

Niewykluczony jest wpływ przeworskiego środowiska bernardynów na powstanie ośrodka kultu św. Antoniego z Padwy w miejscowości Sietesz pod Kańczugą. We wsi oddalonej od Przeworska o ok. 13 km znajdował się kościół pw. św. Antoniego Opata, a miejscową parafię erygowano u schyłku XIV stulecia. Po wzniesieniu w XVII w. kolejnej świątyni zmieniono jej wezwanie na św. Mikołaja. Gdy jednak w 1910 r. wybudowano nowy neogotycki kościół, myreński biskup został jego drugorzędnym patronem, zaś jako głównego przyjęto Antoniego, ale już nie egipskiego opata, ale właśnie Padewskiego. O szczególnej czci oddawanej temuź świętemu przez mieszkańców sieteskiej parafii wspomina bp Wacław Hieronim Sierakowski w relacji wizytacyjnej z 1744 r. Ponadto na skraju wsi zlokalizowana jest kapliczka pw. św. Antoniego ze źródłem. Zgodnie z lokalną legendą Padewczyk odwiedził podprzeworską wieś, a będąc spragnionym, uderzył pątniczą laską o ziemię, powodując wytryśnięcie wody. $\mathrm{Z}$ podaniem tym koresponduje $\mathrm{w}$ pewien sposób obraz $\mathrm{z}$ głównego ołtarza miejscowej świątyni, na którym Antoni przedstawiony jest bez Dzieciątka Jezus, lecz jako pielgrzym ${ }^{70}$. Odnowienie kultu Padewczyka w Sieteszy na przełomie XIX i XX w. było prawdopodobnie skutkiem oddziaływania przeworskiego konwentu bernardynów. Należy

\footnotetext{
${ }^{68}$ J. B e n b e n e k, Eksponaty muzealne o dziejach Przeworska, Przeworsk 1983, s. 171.

${ }^{69}$ A. B e d n a r c z y k, Wtorki św. Antoniego, NEP, 2016, nr 25, s. V.

${ }^{70}$ G. G a r b a c z, Jubileusz. 100-lecia konsekracji kościoła parafialnego w Sieteszy, Rzeszów 2010; A. B e d n a r c z y k, Jeśli szukasz cudów..., NEP, 2010, nr 24.
} 
pamiętać, że okres ten charakteryzował się szczególnie ożywioną działalnością zakonników, którzy wielokrotnie odwiedzali okoliczne parafie z posługą podczas odpustów i z których duszpasterstwa korzystali mieszkańcy okolicznych wsi. Wiemy chociażby, że bernardyni przeworscy przyczynili się do powstania w Sieteszy wspólnoty III Zakonu św. Franciszka, oficjalnie erygowanej w tej miejscowości w 1919 r. $^{71}$. O wpływie duchowości franciszkańskiej na sieteską parafię na pocz. XX w. świadczy ponadto boczny ołtarz św. Franciszka z Asyżu ${ }^{72} \mathrm{z}$ wizerunkiem inspirowanym słynnym dziełem Bartolome Estebana Murillo (kopia obrazu hiszpańskiego malarza znajduje się również w kościele przeworskich bernardynów). Również współcześnie Sietesz pozostaje nadal drugim ośrodkiem kultu św. Antoniego w regionie przeworskim.

Należy także wspomnieć o międzynarodowym aspekcie kultu św. Antoniego w wizerunku przeworskim. W kwietniu 2016 r. na zaproszenie o. Albina Kolarskiego, misjonarza bernardyńskiego na Mauritiusie, o. Marceli Gęśla dokonał oficjalnego wprowadzenia kultu świętego w dwóch miejscowych parafiach na wspomnianej wyspie, umieszczając tam kopie cudownego obrazu z Przeworska ${ }^{73}$.

Ze względu na niesłabnący kult, jakim cieszy się św. Antoni z Padwy w Przeworsku, grupa mieszkańców wystąpiła w 2014 r. z inicjatywą ustanowienia tego świętego patronem miasta. Po przeprowadzeniu odpowiednich konsultacji społecznych, zebraniu kilkuset podpisów wiernych i przy poparciu o. Marcelego Gęśli, gwardiana klasztoru, wniesiono sprawę na obrady Rady Miasta Przeworska. Zaowocowało to uchwałą nr VII/38/2015 ws. wyrażenia woli ustanowienia św. Antoniego z Padwy patronem miasta Przeworska. Wykonanie uchwały powierzono Burmistrzowi Miasta Przeworska, dr. Leszkowi Kisielowi, który przedstawił sprawę metropolicie przemyskiemu, abpowi Józefowi Michalikowi. 17 listopada 2015 r. hierarcha zwrócił się listownie do Kongregacji Kultu Bożego i Dyscypliny Sakramentów w Rzymie z prośbą o zatwierdzenie dokonanego wyboru. 8 kwietnia 2016 r. Kongregacja, działając na mocy uprawnień udzielonych jej

${ }^{71}$ Pamiętnik ogólnopolskiego Kongresu tercyarskiego odbytego w Krakowie z okazyi 700-letniego jubileuszu założenia III Zakonu Św. Ojca Franciszka, 1221-1921, Częstochowa 1922, s. 265, 273.

${ }^{72}$ G. G a r b a c z, op. cit., s. 10.

${ }^{73}$ Sz. W i 1 k, Święty Antoni Przeworski, módl się za nami..., s. 6-7. 
przez papieża Franciszka, wydała dekret zatwierdzający św. Antoniego patronem miasta Przeworska ${ }^{74}$.

Proklamacja dekretu Stolicy Apostolskiej miała miejsce podczas liturgii sprawowanej 13 czerwca 2017 r. w przeworskim kościele bernardynów pod przewodnictwem abpa Adama Szala. Tekst dokumentu odczytał ks. kan. Zenon Ruchlewicz, zaś metropolita przemyski wygłosił kazanie, a po mszy św. dokonał zawierzenia miasta Przeworska św. Antoniemu z Padwy. W czasie celebracji miejscowy chór wykonał specjalnie napisaną i skomponowaną na tę okazję pieśń ku czci Padewskiego „Wielka bez miary Antoniego chwała”, której tytuł nawiązuje do wspomnianego XVIII-wiecznego kazania wygłoszonego podczas jednego z antoniańskich odpustów w Przeworsku ${ }^{75}$.

Ustanowienie św. Antoniego patronem Przeworska wieńczy wielowiekowy kultu Padewczyka praktykowany przez rzesze czcicieli. Choć od namalowania przez mistrza Lekszyckiego przeworskiego wizerunku Chwalebnego Cudotwórcy minęło ponad 350 lat, cześć oddawana świętemu z Padwy jest ciągle żywa. Ukształtowana w duchu barokowej, sarmackiej pobożności rozwijana była przez bernardynów na różne sposoby. Zasługą zakonników stało się stworzenie silnego ośrodka kultu, który przetrwał niezwykle dotkliwy dla przeworskiego konwentu czas zaborów. Wydawać by się mogło, że józefińskie restrykcje i problemy na zawsze pogrzebią antoniańską pobożność w mieście. Jednak dzięki determinacji bernardynów i gorliwej religijności wiernych na przełomie XIX i XX w. nastąpiło odnowienie czci oddawanej św. Antoniemu. Obejmowało ono szereg inicjatyw podjętych przez zakonników (powstanie stowarzyszenia zrzeszającego czcicieli, sprowadzenie partykuły relikwii, wykonanie nowego ołtarza, promowanie responsorium „Si quaeris”), które silnie oddziaływały na mieszkańców miasta i okolicy. Wierni polecali Padewczykowi swoje intencje, a będąc wysłuchanymi, składali świadectwa notowane w księdze cudów i łask. Trosce o rozwój kultu św. Antoniego towarzyszyła zawsze o dbałość o jego obraz jako wybitne dzieło sztuki barokowej. Nic dziwnego, że przeworszczanie zapragnęli, aby święty z Padwy

\footnotetext{
${ }^{74}$ AŚBP, b. sygn., Kult Świętego Antoniego, 2014-2017, b.p.

75 B. Ch m u r a, Święty Antoni będzie się opiekowat mieszkańcami...; eadem, Miasto zostało zawierzone św. Antoniemu, ŻP, 2017, nr 25 (2562), s. 17; Sz. W i 1 k, Św. Antoni z Padwy patronem Przeworska, PŚA, 2017, nr 5, s. 35-36.
} 
został patronem ich miasta. Ufność, jaką mieszkańcy Przeworska pokładają we wstawiennictwie św. Antoniego Padewskiego, wyrażają dobitnie słowa pieśni ku jego czci: „Przeworsk się garnie pod płaszcz Twej opieki, / W której skuteczność wątpić nikt nie może, / Bądź nam Patronem, teraz i na wieki, / Głosić pragniemy wielkie dzieła Boże!’.

\section{Wykaz ilustracji}

Autorem fotografii jest Wojciech Kapusta z Przeworska, jeśli nie zaznaczono inaczej.

1. Fasada zachodnia kościoła OO. Bernardynów w Przeworsku (ok. 1465).

2. O. Franciszek Lekszycki OFMObs, Święty Antoni z Padwy, olej na płótnie, ok. 1645; w ramie neorokokowej wyk. przez Antoniego Rarogiewicza, 1894; kaplica boczna kościoła OO. Bernardynów w Przeworsku (fot. na oktadce $n$ r $132 \mathrm{NP}$ ).

3. Responsorium Si quaeris miracula na kartach kancjonału bernardynów przeworskich; Biblioteka Prowincji OO. Bernardynów w Krakowie, sygn. 53/RL, Cantionale Missarum ad usum Fratrum Minorum Obs. Conventus Preorscensis solerti cura comparatum per R.P. Tacianum Schuldes, ejusdem conventus quardianum vigilantissimum conscriptum die 23 septemb. 1777 anno, s. 170-171.

4. Ks. Józef Ignacy Kocieński, Wielka bez miary chwała Wielkiego Cudotwórcy Świętego Antoniego z Padwy (...) w kazaniu niegdyś mianym w Przeworsku u Wielebnych Ojców Bernardynów ogłoszona, Lwów 1754, fragm., za: Repozytorium Cyfrowe Google Books.

5. Connotatio Miraculorum Imaginis S. Antonii Paduani in Conventu Przevorscensi exsitentis; Biblioteka Jagiellońska, sygn. 98/52, Cathalogus praecipuorum benefactorum loci Przeorscensis ad s. Barbaram V. et M., k. 49r, za: Jagiellońska Biblioteka Cyfrowa.

6. Wierni zapisani do Pobożnego Stowarzyszenia Świętego Antoniego z Padwy w Przeworsku w 1928 r.; Archiwum Prowincji OO. Bernardynów w Krakowie, sygn. IX-13, Księga Stowarzyszenia św. Antoniego przy kościele Bernardynów w Przeworsku, 1917-1938, s. 12-13.

7. Strona z przeworskiej księgi cudów; Archiwum Klasztoru Bernardynów w Przeworsku, b. sygn., [T. Ukleja OFM], Cuda i łaski doznane za przyczyna Matki Bożej Pocieszenia i Świętego Antoniego Padewskiego, 18521960, k. 5v. 
8. Certyfikat autentyczności przechowywanej w zakrystii kościoła OO. Bernardynów w Przeworsku partykuły relikwii św. Antoniego z Padwy wystawiony przez bpa Augustyna Zampiniego OSA, prefekta zakrystii papieskiej, 7 X 1924; Archiwum Prowincji OO. Bernardynów w Krakowie, sygn. IX-1, Akta klasztoru Bernardynów w Przeworsku, 1678-1948, s. 21-30.

9. Kaplica boczna kościoła OO. Bernardynów w Przeworsku (1757) w której w 1962 r. umieszczono ołtarz z obrazem św. Antoniego z Padwy.

10. Wnętrze kaplicy pw. św. Antoniego z Padwy z obrazem mal. przez o. Franciszka Lekszyckiego (ok. 1645) w neorokokowym ołtarzu wyk. przez Antoniego Rarogiewicza (1894).

11. Kartusz z przedstawieniem św. Antoniego z Padwy, XVIII w.; prezbiterium kościoła OO. Bernardynów w Przeworsku.

12. Figura św. Antoniego z Padwy z kapliczki przy ul. Węgierskiej w Przeworsku, XVIII w., obecnie w zbiorach Muzeum w Przeworsku Zespołu Pałacowo-Parkowego, fot. Muzeum w Przeworsku Zespół PałacowoParkowy.

\section{Bibliografia}

\section{Źródła archiwalne}

\section{Archiwum Prowincji Bernardynów w Krakowie}

sygn. IX-1, Akta klasztoru Bernardynów w Przeworsku, 1678-1948.

sygn. IX-12, Księga Trzeciego Zakonu św. Franciszka przy kościele Bernardynów w Przeworsku, 1882-1897.

sygn. IX-13, Księga Stowarzyszenia św. Antoniego przy kościele Bernardynów w Przeworsku, 1917-1938.

sygn. IX-15, Porzadek nabożeństw rocznych przy kościele Bernardynów w Przeworsku, spisany 1919 r.

sygn. IX-41, Księga bractw przy kościele OO. Bernardynów w Przeworsku:

II. Stowarzyszenie św. Antoniego z Padwy, 1915-1925.

sygn. IX-57, Chronica Conventus Przevorscensis Ord. Fr. Minorum vulgo Bernardinorum incip. anno 1884.

sygn. IX-112, Akta klasztoru Bernardynów w Przeworsku, 1848-1974.

sygn. RGP-a-22, Zapiski z wizyty kanonicznej rozpoczętej d. 23.4.1912.

sygn. RGP-b-2, Laconicum novellae provinciae Russiae titulo Immaculatae Conceptionis Beatissimae Virginis Mariae insignitae aliquotque eiusdem locorum et conventum myrrotheicum, seraphico fratrum minorum regularis observantiae ordini mellifcans collectore fratre Bernardino Kaliski, 1647.

sygn. 403, O. Benedykt Wiercioch OFM, Żywoty niektórych bernardynów:

O. Rudolf Waga, Leżajsk 1938-1939. 


\section{Archiwum Klasztoru Bernardynów w Przeworsku}

b. sygn., Liber visitationis (ab an. 1910).

b. sygn., [Tadeusz Ukleja OFM], Cuda i laski doznane za przyczyna Matki Bożej Pocieszenia i Świętego Antoniego Padewskiego, 1852-1960.

\section{Archiwum Parafii pw. Świętej Barbary w Przeworsku}

b. sygn., Kronika parafii św. Barbary w Przeworsku, t. I, 1971-1981.

b. sygn., Kronika parafii św. Barbary w Przeworsku, t. II, 1981-2008.

b. sygn., Kronika parafii św. Barbary w Przeworsku, t. III, od 2008.

b. sygn., Kult Świętego Antoniego, 2014-2017.

\section{Biblioteka Jagiellońska}

rkps 98/52, Cathalogus praecipuorum benefactorum loci Przeorscensis ad s. Barbaram V. et $M$.

Biblioteka Prowincji Bernardynów w Krakowie

sygn. 53/RL, Cantionale Missarum ad usum Fratrum Minorum Obs. Conventus Preorscensis solerti cura comparatum per R.P. Tacianum Schuldes, ejusdem conventus quardianum vigilantissimum conscriptum die 23 septemb. 1777 anno.

Biblioteka Zakładu Narodowego im. Ossolińskich we Wroclawiu

sygn. rkps 384/II, Archivum conventus Prevorscensis ex antiquo transcriptum, cuius originale in bibliotheca asservatur, anno Domini 1767.

\section{Opracowania}

Benbenek J., Eksponaty muzealne o dziejach Przeworska, Przeworsk 1983.

Biedrońska-Krówka D., Kalinowski Rafał, Historia kaplicy zwanej dziś kaplica św. Antoniego w bernardyńskim kościele pod wezwaniem św. Barbary $w$ Przeworsku, $w$ świetle prac konserwatorskich oraz wedtug źródel, [w:] 550 lat obecności oo. Bernardynów w Przeworsku (1465-2015), red. Aleksander Krzysztof Sitnik OFM, Marceli Ryszard Gęśla OFM, Kalwaria Zebrzydowska 2015.

Bruździński A., Bernardyni w Przeworsku w okresie staropolskim, [w:] 550 lat obecności...

Chadam A., Przeworsk, [w:] Klasztory bernardyńskie w Polsce w jej granicach historycznych, red. Hieronim Eugeniusz Wyczawski OFM, Kalwaria Zebrzydowska 1985.

Dworzak A., Przeworski snycerz Antoni Rarogiewicz (1858-1925) - zarys twórczości, „Modus. Prace z historii sztuki”, t. 17, 2017.

Dzik J., Franciszek Lekszycki - malarz religijny baroku, Kalwaria Zebrzydowska 1998.

Garbacz G., Jubileusz 100-lecia konsekracji kościoła parafialnego w Sieteszy, Rzeszów 2010. 
Gąsiorowska P., Rafal Jarosławski - fundator klasztoru bernardynów w Przeworsku, [w:] 550 lat obecności...

Golichowski N., Żywot, cuda i nabożeństwo do św. Antoniego Padewskiego, Kraków 1903.

Grudziński K., Bernardyni w latach 1772-1970, [w:] Zakony św. Franciszka w Polsce w latach 1772-1970, cz. 3, red. Joachim Bar OFM, Warszawa 1978.

Kapusta W., Wilk Szymon, 550 lat Bernardynów w Przeworsku, Przeworsk 2015.

Obruśnik E. A., Obraz św. Antoniego Padewskiego w kościele Ojców Bernardynów w Przeworsku, [w:] 550 lat obecności...

Pamiętnik ogólnopolskiego Kongresu tercyarskiego odbytego w Krakowie z okazyi 700-letniego jubileuszu założenia III Zakonu Św. Ojca Franciszka, 1221-1921, Częstochowa 1922.

Rolska I., Malowane ottarze w kościele oo. Bernardynów w Przeworsku, [w:] 550 lat obecności...

Samek J., Lekszycki Franciszek, „Polski Słownik Biograficzny”, t. 17, 1972.

Sitnik A. K., Bractwa przy bernardyńskim kościele św. Barbary w Przeworsku w okresie staropolskim, „Przeworskie Studia Regionalne”, t. 2, 2015.

Sitnik A. K., Dziatalność bernardynów przeworskich po II wojnie światowej (1944-2014), [w:] 550 lat obecności...

Skrudlik M., Życie i dzieła malarza bernardyńskiego O. Franciszka Lekszyckiego, Sandomierz 1916.

Wilk S., Kult obrazu Matki Bożej Pocieszenia w kościele OO. Bernardynów w Przeworsku, [w:] Matka Boska Podkarpacka. Mniej znane wizerunki, red. Wacław Siwak, Przemyśl 2018.

Wilk S., Kulty wotywne w kościele oo. Bernardynów w Przeworsku w XVII-XVIII w. Zarys problematyki, „Przeworskie Studia Regionalne”, t. 2, 2015.

Wyczawski H. E., Przeworsk (konwent bernardynek), [w:] idem, Klasztory bernardyńskie $w$ Polsce...

\section{Prasa}

Bednarczyk Arkadiusz, Jeśli szukasz cudów..., NEP, 2010, nr 24.

Bednarczyk Arkadiusz, Wtorki św. Antoniego, „Niedziela. Edycja Przemyska”, 2016, $\mathrm{nr} 25$.

Chmura Barbara, Miasto zostało zawierzone św. Antoniemu, „Życie Podkarpackie", 2017, nr 25 (2562).

Chmura Barbara, Święty Antoni będzie się opiekowat mieszkańcami, „Życie Podkarpackie", 2017, nr 23 (2560).

Migdał Bogumił, Z Przeworska: Dzwony, VP, R. 11, 1974, z. 2.

Migdał Bogumił, Z Przeworska: Kościół w nowej szacie, „Vita Provinciae”, R. 16, 1979, z. 1 . 
Migdał Bogumił, Z Przeworska: Uzupetnienia z 1980. Święty Antoni działa, „Vita Provinciae”, R. 18, 1981, z. 2-3.

Przeworsk. Sprawozdanie z działalności Kongregacji III. Zakonu, z ubiegłego r. 1931, „Wiadomości Tercjarskie”, 1932, nr 18.

Wilk Szymon, Jak św. Antoni zawędrowat do Przeworska, „Posłaniec św. Antoniego z Padwy", 2017, nr 4, s. 39-40.

Wilk Szymon, Św. Antoni z Padwy patronem Przeworska, „Posłaniec św. Antoniego z Padwy", 2017, nr 5, s. 35-36.

Wilk Szymon, Święty Antoni Przeworski, módl się za nami, „Niedziela. Edycja Przemyska", nr 26/2016.

\section{SZYMON MAKSYMILIAN WILK}

\section{DZIEJE KULTU ŚWIĘTEGO ANTONIEGO Z PADWY W KOŚCIELE OO. BERNARDYNÓW W PRZEWORSKU}

Streszczenie: W gotyckim, XV-wiecznym kościele oo. Bernardynów w Przeworsku otaczany jest kultem barokowy obraz przedstawiający św. Antoniego z Padwy, autorstwa o. Franciszka Lekszyckiego. Do świadectw czci oddawanej Padewczykowi w okresie staropolskim należą: wydane drukiem kazanie ks. Ignacego Kocieńskiego, czy informacja o pierwszej łasce doznanej za wstawiennictwem św. Antoniego. Po pewnym regresie kultu w okresie józefinizmu, u schyłku XIX w. nastąpiło odnowienie czci wobec Padewczyka, które przypisuje się o. Rudolfowi Wadze. Snycerz Antoni Rarogiewicz wykonał nowy ołtarz dla wizerunku, a w 1895 r. powołano do życia Pobożne Stowarzyszenie Świętego Antoniego z Padwy. Bernardyni odnotowali kilkanaście łask, głównie uzdrowień za wstawiennictwem Padewczyka. W 1962 r. cudowny obraz umieszczono w bocznej kaplicy. O szczególnej czci, jaką darzą świętego przeworszczanie, świadczą rzesze wiernych przybywające nabożeństwo z odśpiewaniem responsorium „Si quaeris miracula” w każdy wtorek. W 2016 r. Kongregacja Kultu Bożego i Dyscypliny Sakramentów ustanowiła św. Antoniego z Padwy patronem miasta Przeworska.

Stowa kluczowe: Franciszek Lekszycki, kult świętych, Przeworsk.

\section{THE HISTORY OF THE CULT OF ST. ANTHONY OF PADUA IN THE BERNARDINE CHURCH IN PRZEWORSK}

\footnotetext{
Abstract: In the gothic $15^{\text {th }}$ century Bernardine church in Przeworsk a baroque portrait of St. Anthony of Padua, painted by Fr. Franciszek Lekszycki is an object of worship. The printed sermon of Fr. Ignacy Kocieński and the information about the first favour granted through the intercession of St. Anthony testify to St. Anthony's
} 
cult in the times of Old Poland. After a certain regression of the cult in the period of Josephinism, in the late $19^{\text {th }}$ century, the worship was renewed, which was attributed to Fr. Rudolf Waga. Antoni Rarogiewicz, a woodcaver, built a new altar for the portrait and in 1895 a Pious Association of St. Anthony of Padua was founded. The Bernardines noted several favours - mainly healings - through the intercession of the saint. In 1962 the miraculous painting was moved to a side chapel. The special reverence with which the inhabitants of Przeworsk treat the saint is visible when multitudes of the faithful attend the service each Tuesday and sing the responsorium „Si quaeris miracula". In 2016, the Congregation for Divine Worship and the Discipline of the Sacraments made St. Anthony of Padua patron of the city of Przeworsk.

Keywords: Franciszek Lekszycki, cult of saints, Przeworsk.

Translated by Hanna Rybkowska 